\title{
RECENZJA PRACY TIMO MEŠKANKA, KULTURA W SEUŽBJE TOTALITARNEHO REŽIMA. WO WOBSTEJNOSĆACH W SERBACH 1948-1989, LUDOWE NAKŁADNISTWO DOMOWINA, BUDYŠIN 2011, SS. 248
}

W swej monografii Timo Meškanka odnosi się do najnowszych dziejów Serbołużyczan, opisuje złożoność relacji narodowościowo-społeczno-kulturalnych po drugiej wojnie światowej na Łużycach. Autor podjął się niełatwego zadania przedstawienia elit mniejszości, ich postaw, zachowań, decyzji kreujących wartości ideologiczne.

Omawiana praca złożona jest $\mathrm{z}$ wstępu, trzech rozdziałów i zakończenia. Przyjęta przez autora stratyfikacja podmiotu badawczego ma charakter ściśle powiązany $\mathrm{z}$ etapami modernizacji pozycji społeczno-narodowościowej Serbołużyczan w Niemieckiej Republice Demokratycznej (NRD). Należy podkreślić, że Serbołużyczanie (słowiańska ludność autochtoniczna), jako mniejszość narodowa uznana przez państwo wschodnioniemieckie, z jednej strony podlegała wpływom i nadzorowi wiodącej Niemieckiej Socjaldemokratycznej Partii Jedności Niemiec (SED), a z drugiej strony polityce Domowiny - organizacji reprezentującej interesy mniejszości serbołużyckiej.

Rozdział pierwszy pracy dotyczy lat 1948-1959 i jest to - jak ujął w tytule rozdziału autor - „Czas stalinizmu i tworzenia podwalin socjalizmu (19481959)". Jest to zarazem szczególny i ważny okres dla budowania nowych odniesień w środowisku mniejszości w powojennej rzeczywistości. Funkcjonowanie pod naporem niemieckich przesiedleńców ze wschodu i pod presją radzieckiej administracji stawia mniejszości w niełatwej sytuacji społeczno-narodowej. Dynamika przemian społeczno-politycznych zdeterminowała wówczas dyskusję o potrzebach i przyszłości narodu serbołużyckiego. Wyzwaniem czasu stało się

\footnotetext{
dr Małgorzata Mieczkowska, Instytut Politologii i Europeistyki Uniwersytet Szczeciński, e-mail: kwietny@gmail.com
} 
poszukiwanie przez działaczy narodowych odpowiedzi na nurtujące mniejszość pytanie: co dla Serbołużyczan jest najlepsze z perspektywy zachowania odrębności i tożsamości narodowej?

Okres stalinizmu zaowocował w opinii autora monografii powstaniem dwutorowego poglądu na sposób zabezpieczania interesów narodowych mniejszości. W jednym z nich działacze Domowiny, a zarazem i członków SED, opowiadali się za ścisłym powiązaniem mniejszości z polityką realizowaną przez państwo. Przedstawiciele drugiego, bardziej powściągliwego kierunku obranego przez kościoły: katolicki i ewangelicki, opowiadali się za stanowiskiem apolityczności narodu serbołużyckiego. O ile organy prasowe mniejszości popularyzowały w tym okresie wartości polityczne przypisane do klasy robotniczo-chłopskiej i współpracę z innymi państwami socjalistycznymi, o tyle pisma kościelne „Pomchaj Boh” i „Katolski Posoł” poddane zostały cenzurze Referatu do Spraw Serbołużyckich w Ministerstwie Spraw Wewnętrznych. W ten sposób chciano wyeliminować publikację zamieszczanych na ich łamach krytycznych wypowiedzi, odnoszących się do realizowanej polityki narodowościowej przez NRD.

System stalinowski był aprobowany przez serbołużyckich działaczy struktur narodowo-politycznych i cechował się instytucjonalną trwałością. Proces destalinizacji w opinii T. Meškanka nie został na Łużycach podjęty przez działaczy narodowych i elity władzy, lecz miał głównie charakter oddolny. Jako potwierdzenie tej tezy przytacza on opis wydarzenia ze szkoły w Pančicach (jest to miejscowość do dziś zamieszkana głównie przez Serbołużyczan) w 1956 roku, w której dzieci zdjęły portret Stalina, by następnie zastąpić go krzyżem. W tym czasie kultura serbołużycka była kształtowana w opinii autora monografii: „według postulatów demokratycznych w formie narodowej”, aby móc balansować pomiędzy socjalistycznym realizmem a niemiecką alternatywą.

Już w 1955 roku okazało się, że nadana w 1948 roku przez państwo wschodnioniemieckie autonomia kulturalna nie jest realizowana. Dychotomia regulacji prawnych i rzeczywistych działań administracji publicznej postawiły mniejszość serbołużycką w roli petenta NRD. Konkluzja, że „niemiecki element jest pasywny, i ani trochę się nie stara, by wspomóc rozwój serbołużyckiej mowy i kultury", przytoczona w monografii, oddaje trafnie obraz sytuacji zdiagnozowanej przez działaczy Domowiny na posiedzeniu w lutym 1955 roku. Z taką oceną sytuacji korespondowały ówczesne odczucia społeczne, w środowisku mniejszości pojawiły się wówczas wypowiedzi: „Dopóki będziemy łączyć życie narodowe z politycznymi i gospodarczymi aspektami, to będziemy prowadzić serbołużyckość ku zagładzie". Tyle, że były one ignorowane przez działaczy Domowiny 
i traktowane jako wrogie wobec niej stanowisko. Taka postawa działaczy wraz z narastającą krytyką otoczenia, według T. Meškanka, przyczyniła się do legitymizacji Domowiny jako elementu totalitarnego systemu.

Kolejnym elementem deprecjacji wiarygodności Domowiny i jej zaplecza instytucjonalnego w tym czasie było opisywanie realiów życia społeczno-narodowościowego mniejszości od czasów nowożytnych do współczesności, głównie w aspektach walki klasowej i wyzysku Serbołużyczan przez klasę kapitalistyczną. Czynnik ideologiczny, ze szczególnym podkreśleniem roli postępowych haseł rewolucji październikowej 1917 roku samostanowienia narodów, przyczynił się do jednostronnej prezentacji dziejów Serbołużyczan przez stulecia. Kontynuacja walki klasowej - w myśl powojennych publikacji - została uwieńczona sukcesem dopiero przez wschodnioniemieckie demokratyczne państwo. Taka interpretacja historii Serbołużyczan, jak zauważa autor pracy, spowodowała z kolei lokowanie mniejszości serbołużyckiej między „,niemieckim szowinizmem a serbołużyckim nacjonalizmem".

Silna presja polityczna SED w 1952 roku przyczyniła się do polaryzacji stanowisk wśród Serbołużyczan wobec idei „Świetlanej przyszłości pod egidą SED”, zintegrowanej z hasłem „, Budujemy socjalizm” i postaw odmowy realizacji tego postulatu. Wystąpienie Błażeja Nawki w 1953 roku, odrzucającego ten postulat publiczną wypowiedzią „Póki żyję nie będę komunistą, wcześniej musiałbym wyrzec się swej narodowości”, dało początek budowaniu alternatywnych postaw i zachowań w obrębie mniejszości. Wszelkie odstępstwa od programowej linii partyjnej SED, realizowanej poprzez Domowinę, wśród mniejszości było traktowane od tego momentu jako potencjalne zagrożenie trendami profaszystowskimi i imperialistycznymi. Wystąpienia podważające ten schemat uznawano za mylne tezy i deprecjonowano jako niewarte podejmowania w publicznej dyskusji.

Zmiany, jakie w ZSRR nastąpiły po śmierci Stalina, zostały na Łużycach zminimalizowane do postulatu, by pokazywać sytuację Serbołużyczan w sposób adekwatny do rzeczywistości, a nie ubarwioną w myśl oczekiwań partyjnych działaczy SED.

17 października 1956 roku z inicjatywy redakcji „Nowej Doby” odbyły się pierwsze powojenne obrady okrągłego stołu, których uczestnicy odnieść się mieli do tezy zamieszczonego artykułu, w którym autor przepowiadał szybki koniec narodu serbołużyckiego. Spotkanie prowadzone przez Maksa Pilopa, ówczesnego redaktora naczelnego dziennika, dało możność zrejestrowania siedemdziesięciu osób w nim uczestniczących. Należy przyjąć, że w ten sposób starano się ustalić liczbę oponentów i stworzyć pozory demokratycznych zachowań działaczy 
Domowiny. Spotkanie nie przyniosło żadnych zmian, nie opublikowano na łamach gazety sprawozdania ani podjętych ustaleń. Równolegle jednak podjęto decyzje o włączeniu do czasopism „Rozhlad” i „Serbska šula” treści ideologicznych.

Rozdział drugi pracy dotyczy lat 1959-1969 i jest ujęty pod tytułem: „Okres zakotwiczenia systemu i duchowego uwolnienia (1959-1969)”. Timo Meškank traktuje ten okres jako czas przemian i rozliczeń, dokonujących się nie tylko na płaszczyźnie ogólnoniemieckiej, ale także w środowisku mniejszości. Efektami poszukiwania winnych wypaczeń systemu było zmuszenie do opuszczenia kraju oponentów politycznych lub ich aresztowania, Niemiecką Republikę Demokratyczną (NRD) w tym czasie opuścił m.in. Marcel Riech-Ranitzki. Opinii publicznej emigrantów politycznych prezentowano natomiast jako zdrajców. Intelektualna sfera u Serbołużyczan u progu lat sześćdziesiątych XX wieku została obsadzona przez rzeczników socrealizmu, którzy skoncentrowali się na realizacji hasła: „NRD - ojczyzna Serbołużyczan jest budowana”. Wówczas do głosu dopuszczono młodych działaczy, którzy po wojnie (w czasach stalinizmu) studiowali w Czechosłowacji i Polsce, mających krytyczny stosunek do zaistniałych wydarzeń. W nowo powstałych serbołużyckich przedsiębiorstwach i instytucjach zaangażowanie młodych ludzi potraktowano instrumentalnie, oferując im świat w czarno-białych barwach. Odrzucano w nim wizję życia, które kłóciło się z radosnym wizerunkiem socjalizmu i propagowanym modelem powszechnego zadowolenia. Odstępstwa od tej zasady spotykały się z krytyką ujętą w recenzjach, np. że ,portret brygadzisty” nie może przedstawiać zmęczonego człowieka. W ten sposób stopniowo, aczkolwiek konsekwentnie, doprowadzono do alienacji systemu od realiów życia na Łużycach.

Postępujący proces asymilacji oceniany w 2010 roku przez Ludwiga Ellego, serbołużyckiego socjologa, został zapoczątkowany w latach pięćdziesiątych m.in. decyzją o stopniowym ograniczaniu języka macierzystego w obrębie rodziny, by docelowo jako jedyny wdrożyć język niemiecki.

Na uwagę zasługuje fakt, że w różnych częściach Łużyc w sposób niejednorodny odniesiono się do nakazów porzucania języka łużyckiego na rzecz języka niemieckiego, przykładowo region Slepjański (ewangelickich Serbów z Górnych Łużyc) nie przyjął tych zaleceń. Na obszarze Środkowych i Dolnych Łużyc, języki górnołużycki i dolnołużyckie zostały wyparte przez język niemiecki, wskutek dokonujących się procesów przesiedleńczych, przy aprobacie władz lokalnych. Przyspieszony proces industrializacji dotychczas rolniczych Łużyc, spotęgował procesy odchodzenia od kultury i języków mniejszości serbołużyckiej. 
Zachowano jednak w pamięci społecznej fakt funkcjonującej odrębności języka, traktując go jako dobro kulturowe poszczególnych regionów Łużyc.

W 1957 roku, podczas Kongresu Domowiny, padły sformułowania wskazujące na brak przyszłości dla języka i kultury łużyckiej. Wypowiedzi działaczy: „Język łużycki nie ma statusu języka światowego, i nie jest nam on do niczego potrzebny” oraz „Nasze wsie leżą na terenach kopalnianych i wkrótce przestaną istnieć. Następnie my przeniesiemy się do Berlina, lub gdzieś indziej, a tam już nie będzie nam potrzebny nasz język" - praktycznie go unicestwiały, całkowicie niszcząc jego prestiż w środowisku mniejszości.

Działacze Domowiny traktowali budowę kombinatów jako szansę stworzenia podwalin pod sformowanie nowego jakościowo narodu serbskiego. Symptomatyczna jest tu wypowiedź przewodniczącego Domowiny Kurta Krjeńca z 1970 roku: „Gdy przyjdzie industrializacja, to Serbowie stracą na znaczeniu i pod wpływem otoczenia przestaną chlubić się serbołużyckością". Efekty nowej polityki językowej, postulowanej przez państwo wschodnioniemieckie i Domowinę, najszybciej - już u progu lat sześćdziesiątych - uwidoczniły się na Dolnych Łużycach. Autor pracy Kultura $w$ stužbje totalitarneho režima... podkreśla, że mamy tu do czynienia ze schizofrenią elit mniejszości, które z jednej strony mówiły wiele o łużyckości, a z drugiej robiły wszystko, by jej nie było. Potwierdzenie tego, jak zła była taka polityka dla zachowania tożsamości narodowej mniejszości, znajdujemy w przytaczanych przez niego statystykach szkolnych.

Przykładowo w 1964 roku wprowadzenie fakultatywności nauczania w języku górnołużyckim spowodowało spadek liczby uczniów nim zainteresowanych z 12800 (1962 r.) do 3200 (1964 r.). Jest to czas, kiedy, w ocenie autora monografii, zadecydowano o utracie łużyckości. Spadek ten był podobnie oceniany przez najwybitniejszego współczesnego łużyckiego pisarza Jurija Brĕzana, wówczas powstał utwór, przez wiele lat pozostawiony w szufladzie, zatytułowany „Jak utraciłem ojczyznę".

Podporządkowanie Domowiny przez SED w walce z kościołami: ewangelickim i katolickim na Łużycach w latach pięćdziesiątych i na początku lat sześćdziesiątych XX wieku spowodowało, że organizacja ta po 1964 roku została osamotniona na polu walki o prawa językowe. Tracąc mandat zaufania społecznego - w ocenie T. Meškanka - utraciła prawo do reprezentowania interesów narodu serbołużyckiego.

Ocena roli Domowiny w tych procesach, prezentowana kilkadziesiąt lat później w czasie przemian politycznych w NRD, w 1990 roku ma jednoznacznie krytyczny charakter: „Pierwszy zamiar Domowiny, to powielanie modelu 
ideologicznego państwa, a wśród Serbołużyczan w szczególności ateistyczno-marksistowskiego światopoglądu". Przedmiotowe traktowanie języka przez decydentów Domowiny znalazło potwierdzenie w publicznych wypowiedziach jej działaczy. Autor pracy przytacza, jako potwierdzenie takiego stanowiska Domowiny, wypowiedź Kurta Krjeńca, jej przewodniczącego: „Wiemy, że mowa macierzysta to ważny i pomocny emocjonalny faktor, który ma natchnąć serca młodzieży do kreowania życia organizacyjnego a także poprzez racjonalność wzmacniać naszą socjalistyczną ojczyznę".

Rozdział trzeci monografii zatytułowany: „Okres normalizacji i utrwalanie systemu (1969-1989)" to opis kierunku zmian i działań po Praskiej Wiośnie, która została przyjęta przez Serbołużyczan z entuzjazmem i z obawami zarazem. Na VII Kongresie Domowiny Jurij Grós - kolejny przewodniczący - scharakteryzował cechy nowego socjalistycznego obywatela NRD, Serbołużyczanina. W tym nowoczesnym ujęciu przedstawiono go jako jednostkę walczącą o ideały i zarazem działacza oddanego ideom kolektywnego myślenia i działania służącym socjalistycznemu patriotyzmowi i internacjonalizmowi. W tym okresie w obrębie Domowiny zdecydowano o podjęciu walki z tzw. -izmami, to jest: szowinizmem narodowym, panslawizmem politycznym, antykomunizmem, rewizjonizmem, imperializmem, liberalizmem. „Polityczny slawizm jest blisko nacjonalizmu, a to może mieć rewizjonistyczne konsekwencje" pisano wówczas na łamach prasy serbołużyckiej.

Stagnacja i rezygnacja to elementy przypisane, w opinii T. Meškanka, do życia literackiego lat siedemdziesiątych XX wieku, mające także potwierdzenie w odczuciach społecznych w obrębie mniejszości na Łużycach. Kreowany celowo wiejski styl życia, stwarzający iluzję sielanki i dobrobytu na Łużycach, stał się utrwalonym propagandowym obrazkiem sukcesów socjalistycznych tego obszaru - był on szczególnie atrakcyjny dla gości z zewnątrz, którzy przyjmowali go z entuzjazmem podczas organizowanych Festiwali Kultury Serbołużyckiej. Takiego aplauzu nie uzyskiwano już na obszarach zdegradowanych ekologicznie, kiedy prezentowano osiągnięcia socjalistycznej industrializacji Łużyc, gdy wieziono gości do Czarnej Pompy - Kombinatu Węglowo-Energetycznego.

Jak podaje T. Meškank, do momentu upadku reżimu około stu osób otwarcie zadeklarowało swój sprzeciw wobec polityki kulturalnej realizowanej w NRD. Na Łużycach tylko pojedyncze osoby domagały się od władz Domowin rzetelnych i wiarygodnych informacji. Kontestowały one propagandę sukcesu postulując, by realnie oszacowano bilans zysków i strat poniesionych przez mniejszość na skutek postępującej industrializacji. Dyskryminacja i cenzura równolegle 
wymuszały postawy konformizmu wśród inteligencji serbołużyckiej, co znalazło potwierdzenie w literaturze pięknej oraz filmach tworzonych w tym czasie. Pozornie dokonywane zmiany i ewolucji systemu starano się do końca istnienia NRD ujmować jako rzeczywiste i zasadne w środowisku mniejszości. W gruncie rzeczy były one jednak fikcją, gdy pod koniec 1988 roku w Dreźnie grupa studentów pod egidą m.in. Timo Meškanka założyła niezależne pismo „Serbski student”, natychmiast potraktowano to działanie jako antypaństwowe i szkodliwe dla interesów mniejszości. O ile działacze Domowiny negowali potrzebę podejmowania dyskusji na łamach pisma, o tyle środowiska kościelne i ekologiczne wskazywały na konieczność jej prowadzenia. Wybory komunalne na Łużycach w maju 1989 roku potwierdziły sukces polityczny SED i Domowiny, ale wobec dokonujących się przemian politycznych w NRD ich wynik w listopadzie tego samego roku został zinterpretowany jako całkowita porażka Domowiny. Z tej to przyczyny 11 listopada 1989 roku w Budziszynie ogłoszono powołanie Serbołużyckiego Zgromadzenia Narodowego, mającego na celu wprowadzenie przekształceń o charakterze demokratycznym w obrębie mniejszości serbołużyckiej.

Ostatnim elementem omawianej pracy, obok uwag edytorskich dotyczących translacji zapisów o charakterze ortograficznym, wykazu skrótów, bibliografii oraz indeksu nazwisk, jest część zatytułowana „Zakończenie albo też aposteriori”.

Jest to część pracy koncentrująca uwagę czytelnika na wielu przytaczanych wypowiedziach osób znanych i uznanych przez środowisko mniejszości. W ten dość jaskrawy sposób autor zaznacza, a przez co i poniekąd wartościuje, ich postawy społeczno-polityczne.

Przedmiotowe traktowanie mniejszości przez elity władzy NRD nie jest jednak w jego ocenie jedyną przyczyną budowania postaw bezkrytycznej aprobaty dla decyzji o charakterze antynarodowym. W zasadniczej mierze to polityka ustępstw i biernej akceptacji władz Domowiny przyczyniły się do jej pauperyzacji społeczno-politycznej, stawiając na straconej pozycji wobec dogmatów ideologicznych NRD. Przekonanie, że NRD jest jedynym państwem, które zabezpiecza egzystencję i interesy narodowe mniejszości serbołużyckiej, w ocenie autora pracy stało się początkiem końca wolności w obrębie mniejszości. Gloryfikowana przez dziesięciolecia lojalność ideologiczna docelowo obróciła się przeciwko mniejszości, niszcząc jej potencjał i samodzielność w rozwiązywaniu problemów mniejszości.

O tym, jak jest to utrwalony model, zaświadcza konstatacja autora, iż nawet podjęte próby rozliczenia się z przeszłością sprowadza się do zbiorowej 
odpowiedzialności przypisanej do SED, a nie do rzeczywistych działań osób pochodzących ze środowiska mniejszości.

Recenzowana monografia jest niezmiernie ważna z perspektywy pluralizmu badawczego, przedstawiającego etapy przemian dokonujących się na płaszczyźnie szeroko pojmowanej kultury w obrębie jedynej mniejszości narodowej w NRD. Dotychczas opublikowano już wiele prac podejmujących i rzetelnie analizujących realizowaną przez wschodnioniemieckie państwo politykę narodowościową, ale zazwyczaj prezentowano w nich konieczność przyjmowania narzucanych kierunków rozwoju. Podkreślano w nich przedmiotowe traktowanie elity mniejszości przez państwo wschodnioniemieckie i brak zaplecza politycznego, umożliwiającego zanegowanie odgórnych decyzji. W tym przypadku mamy do czynienia z jednoznacznym stanowiskiem autora, że Serbołużyczanie nie tylko byli ofiarami komunistycznego systemu, ale i sami gorliwie pracowali na rzecz jego wdrożenia. Ta nader krytyczna i nie do końca przemyślana, jak się wydaje, teza badawcza, nie mogła spotkać się z pozytywnym odbiorem w środowisku mniejszości. Powodując jednak publiczny dyskurs na temat doświadczeń społeczno-politycznych mniejszości w okresie powojennym, dała asumpt do weryfikacji dotychczas prezentowanych opinii i stanowisk badawczych. Niestety dość jednostronnie skonstruowany tok przyjętej narracji o charakterze krytycznym budzi wątpliwości, czy został $\mathrm{w}$ tym przypadku zachowany chłodny obiektywizm badawczy. Momentami w pracy uwidacznia się emocjonalne ujęcie faktów, co niewątpliwie szkodzi publikacji.

Bogaty zasób zebranych wypowiedzi, cytatów i prezentowany kontekst sytuacji międzynarodowej stanowią dobre cechy monografii. Sorabistów cieszy szeroka prezentacja środowisk twórczych, funkcjonujących w obrębie mniejszości serbołużyckiej w dobie NRD. Szkoda jednak, że zabrakło ikonografii, która z pewnością stanowiłaby interesujące uzupełnienie omawianej publikacji. 